\title{
Ectoparasites of bats (Chiroptera, Furipteridae), with a description of a new species of Synthesiostrebla Townsend (Diptera, Streblidae) from Brazil
}

\author{
Gustavo Graciolli ${ }^{1,3}$ \& Alexsander Araújo Azevedo²
}

\begin{abstract}
'Departamento de Biologia, Centro de Ciências Biológicas e da Saúde, Universidade Federal de Mato Grosso do Sul, Caixa Postal 549, 79070-900 Campo Grande-MS, Brasil.ggraciolli@yahoo.com.br

${ }^{2}$ Instituto Biotrópicos, Beco do Izidoro, 12A, Centro, 39100-000 Diamantina-MG, Brasil.

${ }^{3}$ Fellowship CNPq
\end{abstract}

\begin{abstract}
Ectoparasites of bats (Chiroptera, Furipteridae), with a description of a new species of Synthesiostrebla Townsend (Diptera, Streblidae) from Brazil. Records of ectoparasites from furipterid bats are restricted to bat flies (Streblidae). Only three streblid species were known before this work: Trichobius pallidus (Curran, 1934), Strebla wiedemanni Kolenati, 1856, and Synthesiostrebla amorphochili Townsend, 1913. A second species of Synthesiostrebla is described here, increasing the geographical distribution of the genus to east of the Andes. Synthesiostrebla cisandina sp. nov. was found on Furipterus horrens (Cuvier, 1828) in southeastern Brazil. Anterior parts of the body, wing, tergite 7, epiproct and male genitalia are illustrated, and a key to females for species of Synthesiostrebla is provided.

KEYWORDS. Bat flies; Brazil; cis-andean; Furipteridae; taxonomy.

RESUMO. Ectoparasitos de morcegos (Chiroptera, Furipteridae), com a descrição de uma nova espécie de Synthesiostrebla Townsend (Diptera, Streblidae) do Brasil. Os poucos dados sobre ectoparasitismo em morcegos furipterídeos são restritos a moscas (Streblidae). Somente três espécies de estreblídeos eram conhecidas antes desse trabalho: Trichobius pallidus (Curran, 1934), Strebla wiedemanni Kolenati, 1856, and Synthesiostrebla amorphochili Townsend, 1913. Outra espécie de Synthesiostrebla é descrita aqui aumentando a distribuição geográfica do gênero para o lado leste dos Andes. Synthesiostrebla cisandina sp. nov. foi encontrada sobre Furipterus horrens (Cuvier, 1828) no sudeste do Brasil. Região anterior do corpo, asa, tergito 7, epiprocto e genitália masculina são ilustrados e uma chave de identificação para fêmeas também é apresentada.
\end{abstract}

PALAVRAS-CHAVE. Moscas ectoparasitas de morcegos; Brasil; cis-andina; Furipteridae; taxonomia.

Townsend (1913) erected Synthesiostrebla (Diptera, Streblidae) as a monotypic genus, describing a new species, Synthesiostrebla amorphochili, based on a female specimen collected on Amorphochilus schnablii (Chiroptera, Furipteridae) from Piura $\left(5^{\circ} 12^{\prime} \mathrm{S}, 80^{\circ} 38^{\prime} \mathrm{W}\right)$, Peru. The species was later redescribed by Jobling (1947), who used another female specimen that was collected on the same host species from Tambo Valley, east Chucarapi (17¹0'S, $\left.71^{\circ} 44^{\prime} \mathrm{W}\right)$, Arequipa, Peru. For almost 100 years since original description, Synthesiostrebla was considered a monotypic genus, with a geographical distribution restricted to the west side of the Andes, mirroring its host's distributional range (Fig. 1).

The few records of ectoparasites of furipterid bats are restricted to Streblidae. In addition to Synthesiostrebla, Wenzel et al. (1966) noted an undescribed species of Trichobius pallidus group on A. schnablii from Peru, and Guerrero (1994) recorded Trichobius pallidus (Curran, 1934) on F. horrens from Guyana and Venezuela. Graciolli et al. (2008) recorded $T$. pallidus and Strebla wiedemanni Kolenati, 1856, an accidental record, on F. horrens in Brazil.

Furipteridae comprises two monotypic genera of bats, Amorphochilus Peters, 1877 and Furipterus Bonaparte, 1837
(Simmons 2005). Amorphochilus schnablii Peters, 1877 is distributed west of the Andes in Ecuador, Peru, and Chile (Barquez \& Diaz 2008), while Furipterus horrens (Cuvier, 1828) has a broader distribution, found in Costa Rica, Trinidad, and in northern South America, including Peru and east into large portions of Brazil (Miller et al. 2008) (Fig. 1).

Here, we describe a new species of Synthesiostrebla collected on F. horrens from Minas Gerais, Southeastern Brazil, establishing a disjunct distribution of the two species known from the genus.

\section{MATERIAL AND METHODS}

Morphological terminology follows Wenzel \& Peterson (1987). Measurements were made with the aid of Leica (LAS Leica $^{\mathrm{TM}}$ software. Body length was measured from the anterior margin of the palpi to the apex of the abdomen. Specimen images were made on microscopy M205 with camera DF420C and processed by Leica (LAS Leica ${ }^{\mathrm{TM}}$ ) software. Type material has been deposited at Museu de Zoologia da Universidade de São Paulo, São Paulo, Brazil (MZSP). 


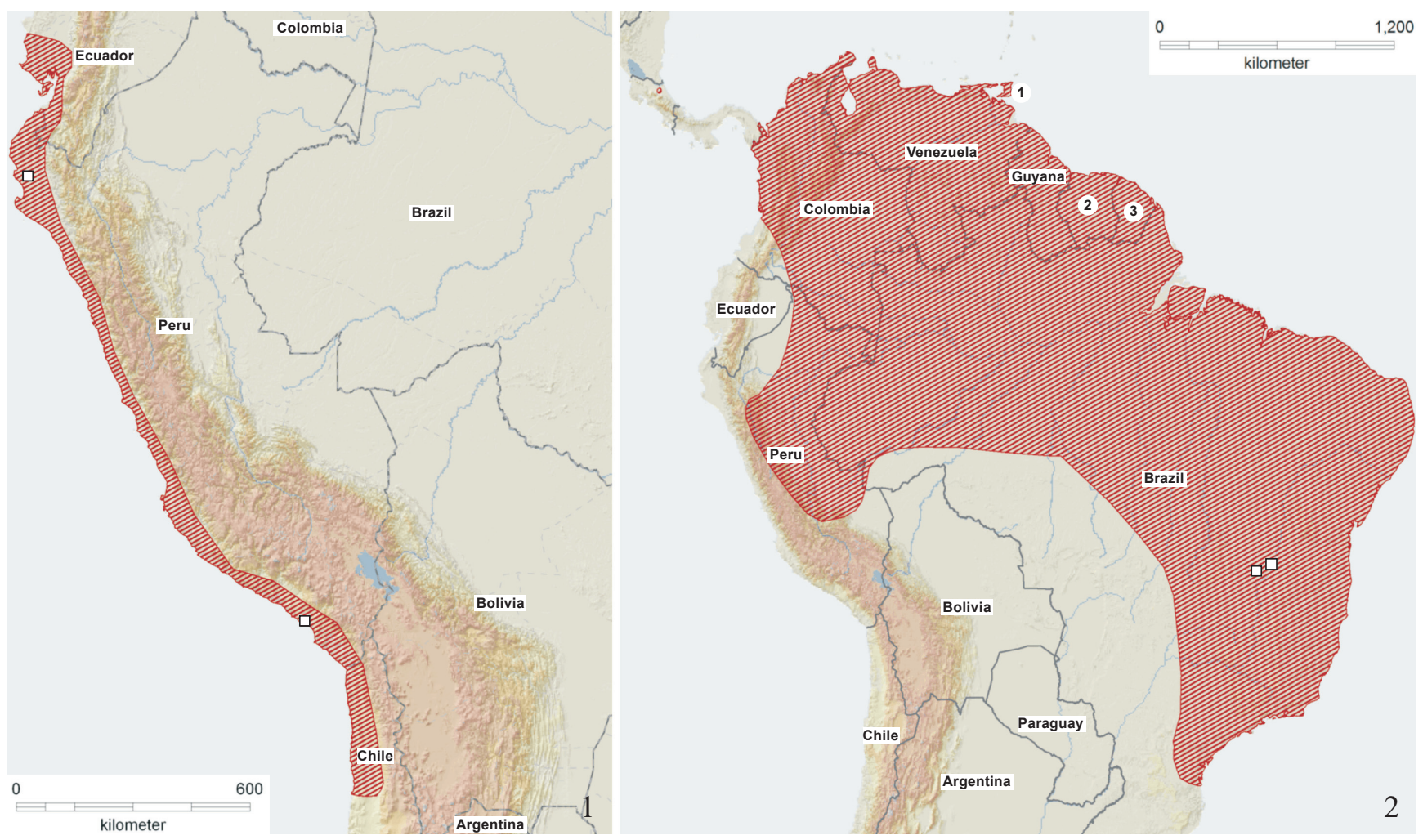

Figs. 1-2. Geographical distribution of the hosts (Chiroptera: Furipteridae) (shared area) and their parasites species of Synthesiostrebla (Diptera: Streblidae), indicating restricted localities where the last ones were recorded: 1. Amorphochilus schnablii Peters and Synthesiostrebla amorphochili Townsend modified of Barquez \& Diaz (2008). 2. Furipterus horrens (Cuvier) and Synthesiostrebla cisandina sp. nov.; 1, Trinidad; 2, Suriname; 3; French Guiana - modified of Miller et al. (2008).

\section{RESULTS AND DISCUSSION}

\section{Synthesiostrebla Townsend, 1913}

Townsend, 1913: 99. Type species: Synthesiostrebla amorphochili, by original designation.

Bequaert, 1942: 85 (key). Jobling, 1947: 39 (redescription). Wenzel et al., 1966: (key).

Diagnosis (modified from Jobling (1947)). Occipital lobes broadly rounded. Mediovertex with elliptical sclerite. Middle of anterior margin of prescutum with 2 closely placed, sharp teeth which fit into grooves on the posterior part of the head (Figs. 3-5); proespisternum 1 strong (Figs. 4-5), with flat projections which fit under posteroventral margin of head. Scutellum broadly triangular, with four setae, two long and discal and two short, each near the lateral margins (Fig. 3). Mesosternum narrower than mesonotum. Leg 3 as long as body (Fig. 3). Tibiae 1 with a row of eight strong setae on the antero-dorsal surface. $\mathrm{R}$ vein curved. $\mathrm{R}_{2+3}$ up to $\mathrm{C}$. $\mathrm{r}-\mathrm{m}$ near fork of Rs (Figs. 3, 6).

\section{Synthesiostrebla cisandina sp. nov.}

(Figs. 2, 5-9)

Description. Body length (on slide). Holotype female $1.735 \mathrm{~mm}$; male $1.599 \mathrm{~mm}$

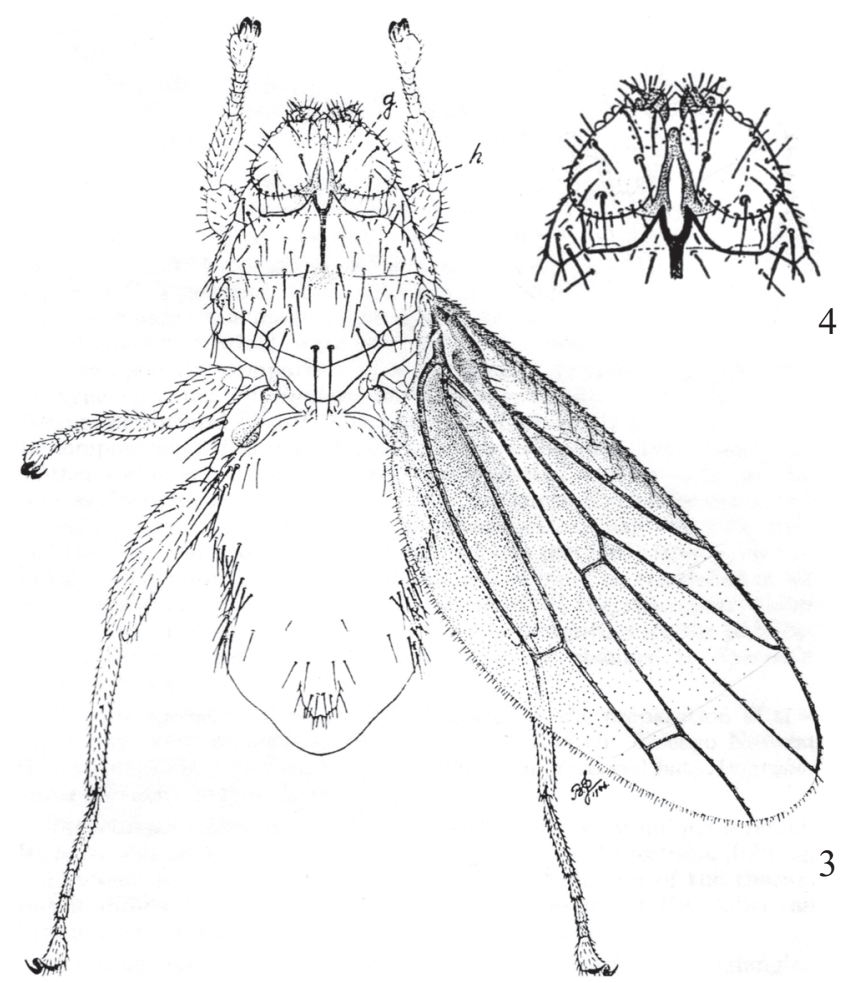

Figs. 3-4. Synthesiostrebla amorphochili: 3, habitus, dorsal view - after Jobling (1947); 4, head and anterior part of thorax, dorsal view - after Jobling (1949). Abbreviations: G: occipital lobe; h: proespisternum 1. 
Head. Laterovertex short, lobed, and with seven setae (Fig. 5). Occipital lobes with 18 sparse setae (Fig. 5).

Thorax. Teeth in the anterior margin of prescutum each with an apical seta (Fig. 5). Five to six spiniform setae near the anterior margin of prescutum. Each side of prescutum with 18 to 21 setae. Longitudinal suture united with transverse suture. Scutum with 24 discal setae and about 10 antescutellar setae (Fig. 6). Two episternal setae. Legs, femur 1 with a row of six strong setae on dorsal surface. Basitarsum 3 as long as following two tarsomeres combined. Wing, $\mathrm{R}$ with two setae; $\mathrm{M}_{4}+\mathrm{Cu}_{1}\left(\mathrm{Cu}_{1}\right)$ with two long setae (Fig. 7).

Abdomen. Lateral connexivum with long setae. Female. Tergite 7 transverse and united to epiproct, with two pairs of lateral setae of similar length (Fig. 8). Epiproct with four long setae and one pair of discal setae (Fig. 8). Sternite 2 with 19 discal setae and 11 along the posterior margin. Sternite 7 divided in two semicircles, each with 12-13 setae. Male. Sternite 2 with 14 discal setae and eight alongthe posterior margin. Sternite 5 subtriangular with 27 discal setae and 12 along the posterior margin, some of which are as long or longer than sternite 5 . Syntergosternite $7+8$ with three setae on each side. Gonopods curved with two gonopophyseal setae of similar length (Fig. 9).

Holotype. 1 female (MZSP), Brazil, Minas Gerais, Itacarambi $\left(44^{\circ} 05^{\prime} \mathrm{W}, 15^{\circ} 05^{\prime} \mathrm{S}\right)$ on Furipterus horrens, 09/ XII/1997; A.A. Azevedo leg.

Paratype. 1 male (MZSP), Brazil, Minas Gerais, Cavernas do Peruaçú National Park (44'27'W, $15^{\circ} 48^{\prime}$ S ) on F. horrens, 10/XII/1997; A.A. Azevedo leg.

Etymology. The name "cisandina" is a reference to "cisandean", signifying that this is the first distributional record of Synthesiostrebla from opposite sides of the Andes.

The taxonomic key below can be used to identify only females of Synthesiostrebla, because the male of $S$. amorphochili is unknown.

\section{Key to the species Synthesiostrebla (females)}

1. Body length: 1.0 to $1.4 \mathrm{~mm}$. Occipital lobes greatly developed, covering the laterovertex (Figs. 3-4). Teeth on the anterior margin of prescutum without apical setae. Basitarsum 3 as long as following four tarsomeres combined (Fig. 3). Wing, R with four to five setae; $\mathrm{M}_{4}+\mathrm{Cu}_{1}\left(\mathrm{Cu}_{1}\right)$ with three long setae (Fig. 3). Epiproct with two pair of discal setae (Fig. 3)

Synthesiostrebla amorphochili Townsend

1'. Body length: $1.735 \mathrm{~mm}$. Occipital lobes not covering the laterovertex (Fig. 5). Teeth on the anterior margin of prescutum each with an apical seta (Figs. 5-6). Basitarsum 3 as long as following two tarsomeres combined. Wing, $\mathrm{R}$ with two setae; $\mathrm{M}_{4}+\mathrm{Cu}_{1}\left(\mathrm{Cu}_{1}\right)$ with two long setae (Fig. 7). Epiproct with one pair of discal setae (Fig. 8)

Synthesiostrebla cisandina sp. nov.

The degree of occipital lobe development, presence of mesonotal teeth and strong proespisternum 1 in Synthesiostrebla are characteristics unique among the streblid bat flies. Wenzel et al. (1966) aligned (albeit doubtfully), Synthesio-
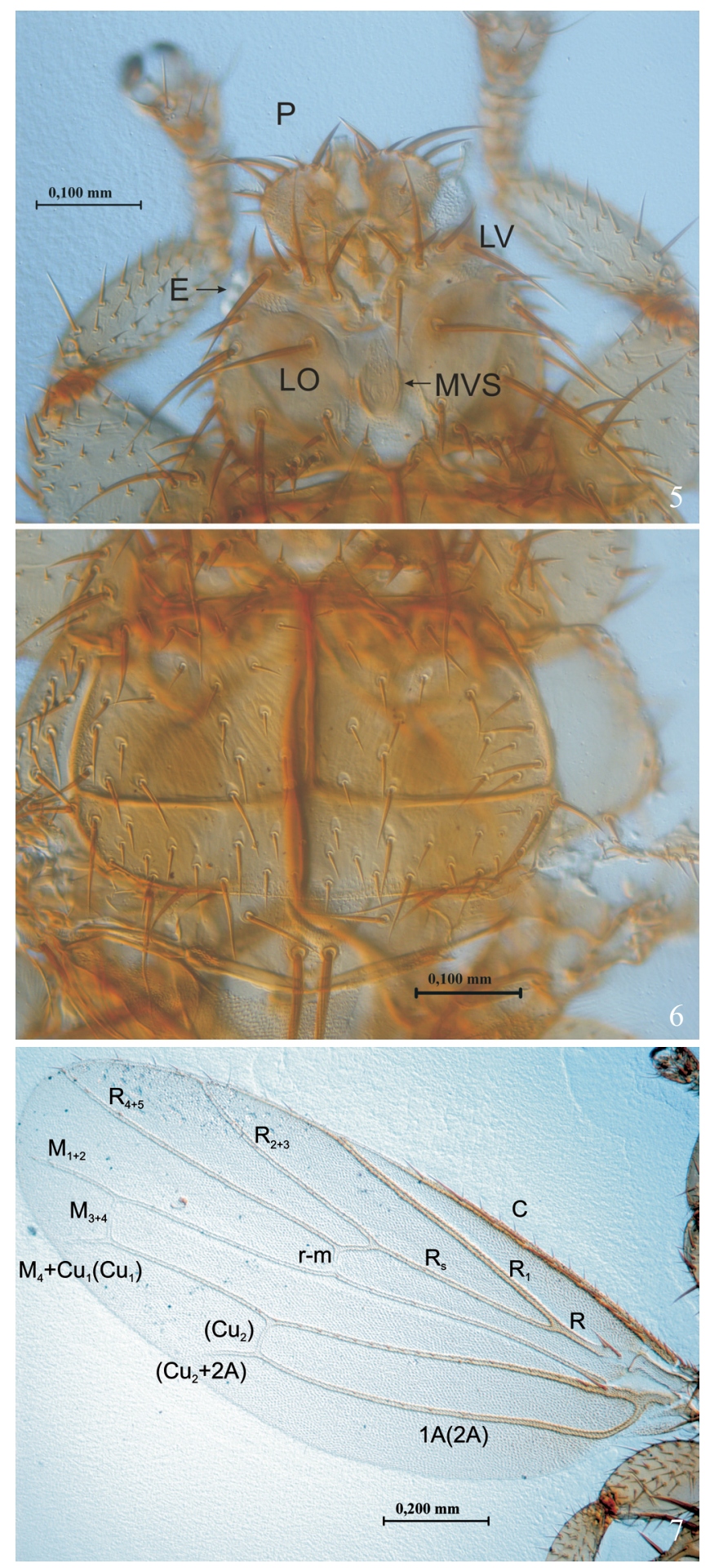

Figs. 5-7. Synthesiostrebla cisandina sp. nov.: 5, head, dorsal view; 6, mesonotum; 7, wing. Abbreviations: E: eye; LO: occipital lobe; LV: laterovertex; MVS: mediovertex sclerite; P: maxillary palp.

strebla near to Trichobius pallidus within the Trichobiinae.

A female of T. pallidus was also collected on the same bat individual that hosted the male paratype of $S$. cisandina. This record re-confirms the relation between this bat fly species and F. horrens, as have been related previously (Guerrero, 1994; Graciolli et al. 2008). 

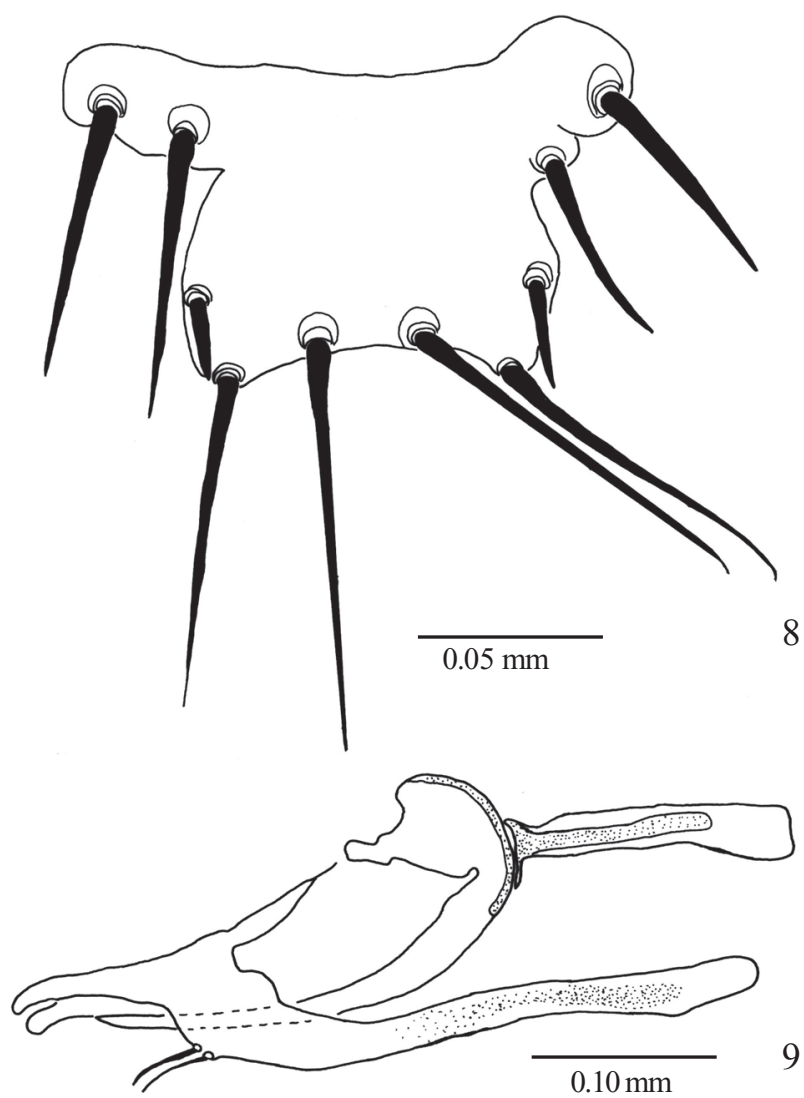

Figs. 8-9. Synthesiostrebla cisandina sp. nov.: 8, tergite 7 and epiproct; 9 , male genitalia.

Graciolli \& Dick (2009) pointed out that when a bat fly species occurs exclusively on a host species that is threatened or endangered of extinction, it also should receive at least the same heightened status as the host. As Synthesiostrebla amorphochili parasites a bat species considered endangered by IUCN (Barquez \& Diaz 2008), we consider this bat fly to be endangered as well. However, the same consideration cannot be affirmed for $S$. cisandina.

Parasitological indices are not yet available for Synthesiostrebla. Only two specimens of each species are known in the literature. The distribution of these bat flies species likely corresponds to the distribution of their respective host species. Alternatively, $S$. cisandina may be considered rare in nature. Although its host, F. horrens, has a wide distribution, it is known to be rare locally (Miller et al. 2008). More information is needed to understand these host-parasite relationships.

\section{ACKNOWLEDGEMENTS}

We would like to thank Dra. Valéria da Cunha Tavares by identification of the host bats and by coordination of the expedition that resulted in collection of this new bat fly species and Carl W. Dick for reviewing the English.

\section{REFERENCES}

Barquez, R. \& M. Diaz. 2008. Amorphochilus schnablii. In: IUCN 2010. IUCN Red List of Threatened Species. Version 2010.4 www.iucnredlist.org (accessed 12th January 2011).

Bequaert, J. 1942. The Diptera Pupipara of Venezuela. Boletín de Entomología Venezolana 1: 79-88.

Graciolli, G.; A. A. Azevedo; M. Árzua; D. M. Battesti \& P. M. Linardi. 2008. Artrópodos ectoparasitos de morcegos no Brasil, p. 123-138. In: S. Pacheco; R. V. Marques \& C. E. L. Esbérard (orgs.). Morcegos do Brasil: biologia, sistemática, ecologia e conservação, $1^{\text {a }}$. edição. Porto Alegre, Armazém Digital, 504 p.

Graciolli, G. \& C. W. Dick. 2009. A new species of Basilia Miranda-Ribeiro (Diptera: Nycteribiidae) from Honduras, parasite of Bauerus dubiaquercus (Van Gelder) (Chiroptera: Vespertilionidae: Antrozoinae). Zootaxa 1972: 59-64.

Guerrero, R. 1994. Catalogo de los Streblidae (Diptera: Pupipara) parasitos de murciélagos (Mammalia: Chiroptera) del Nuevo Mundo. II. Los Grupos: pallidus, caecus, major uniformis y longipes del Genero Trichobius Gervais. Acta Biológica Venezuélica 15: 1-18.

Jobling, B. 1947. On Speiseria ambigua Kessel and Synthesisostrebla amorphochili Townsend, with a redescription of the latter (Diptera, Streblidae). Proceedings of the Royal Entomological Society of London, Series B, Taxonomy, 16: 39-41.

Jobling, B. 1949. Host-parasite relationship between the American Streblidae and the bats, with a new key to the American genera and a record of the Streblidae from Trinidad, British West Indies (Diptera). Parasitology 39: 315-329.

Miller, B.; F. Reid; J. Arroyo-Cabrales; A. D. Cuarón \& P. C. de Grammont. 2008. Furipterus horrens. In: IUCN 2010. IUCN Red List of Threatened Species. Version 2010.4. www.iucnredlist.org (accessed 12th January 2011).

Simmons, N. S. 2005. Order Chiroptera, p. 312-529. In: D. E. Wilson \& D. M. Reeder (eds) Mammal species of the world: a taxonomic and geographic reference. Baltimore, Johns Hopkins University Press, 2142p.

Townsend, C. H. T. 1913. A new Genus of Streblidae. Proceedings of the Entomological Society of Washington 15: 98-99.

Wenzel, R. L.; V. J. Tipton \& A. Kiewlicz. 1966. The streblid batflies of Panama (Diptera: Calypterae: Streblidae), p. 405-675. In: R. L. Wenzel \& V. J. Tipton (eds.). Ectoparasites of Panama. Chicago, Field Museum of Natural History, xii +861 .

Wenzel, R. L. \& B. V. Peterson. 1987. Streblidae, p. 1293-1301. In: J. F. McAlpine, B. V. Peterson, G. E. Shewell, H. J. Teskey, J. R. Vockeroth \& D. M. Wood (Eds.). Manual of Nearctic Diptera. Vol. 2. Ottawa, Agriculture Canada, Monograph 28, i-vi, 657p. 